\title{
Theoretical model for neurovascular coupling via interactions of NO, EET, and 20-HETE
}

\author{
Hyuk Kang ${ }^{1 *}$, Jung-Min Lee ${ }^{1}$, Misun Kim², Dong-Uk Hwang ${ }^{1}$ \\ From Twenty Second Annual Computational Neuroscience Meeting: CNS*2013 \\ Paris, France. 13-18 July 2013
}

All neurons in the brain need the energy sources such as glucose and oxygen for their functions such as recognition, decision, and behavior regulation. Those energy sources are supplied directly from the capillary around the neuron, or are transported indirectly via the astrocyte. Especially, since more activated neuron consumes more energy sources, the neuron elevates intakes of glucose and oxygen via increasing the blood flow of vessels around itself. Therefore, the blood flow in the brain is important medically, and is one of major parameters in measurement of the brain activity such as functional magnetic resonance image (fMRI) and Near-infrared Spectroscopy (NIRS).

In many experiments, it has been discovered that neuron and astrocyte regulates the brain blood flow via the generated vasoactive agents from them [1]. Usually, vasoactive agents are directly generated from the activating neuron, or are produced indirectly from the stimulated astrocyte by the released neurotransmitter from the neuron. Those vasoactive agents dilate or contract the blood vessel via action on its smooth muscle cells, and there are several kinds of them: NO, EET, prostaglandin, 20-HETE, and so on. But vasoactive agents have no additive effect [2]. For example, although $\mathrm{NO}$ inhibitor is added to the blood with EET inhibitor, the inhibition effect shows no increase [3]. In addition, NO sometimes inhibits the effects of EET or 20-HETE [1,4]. Therefore, the temporal or spatial roles for functional hyperemia by vasoactive agents, neuron and astrocyte become an object of attention, and, if interactions and equivalence between dilation and contraction materials are known in their system, it provides the information about the detailed neurovascular modulation.

\footnotetext{
* Correspondence: kh9395@nims.re.kr

${ }^{1}$ National Institutes for mathematical Sciences, Daejeon, 305-811, Republic of Korea

Full list of author information is available at the end of the article
}

As previously described, although the mathematical model should importantly consider the coupled effect of vasoactive agents, present modeling studies have been represented via independent interaction between vasoactive agent and vessel. Therefore, we propose the multi-compartment mathematical model, which consists of postsynaptic neuron, astrocyte, and smooth muscle cell of vessel. It is described by the following sequence: 1 ) the activated presynaptic neuron triggers glutamate release, 2) the glutamate binds to the metabotropic receptor of astrocyte or NMDA receptor of postsynaptic neuron, 3) the bounded glutamate increases the calcium concentration in both astrocyte and neuron, 4) the calcium concentration increase creates arachidonic acid in astrocyte and NO in neuron, 5) the arachidonic acid is metabolized to transform EET or 20-HETE, which are inhibited partly by NO, 6) EET increase the $\mathrm{K}+$ channel conductance of smooth muscle cell (SMC), 7) 20-HETE decreases the K+ channel conductance of SMC, 8) SMC is hyperpolarized via the outward $\mathrm{K}+$ influx, 9) voltage-dependent $\mathrm{Ca} 2+$ channel of SMC is deactivated, and $\mathrm{Ca} 2+$ concentration decreases, 10) the contraction force of SMC decreases, so that vessel dilates. From the mathematical model, we obtain the simulation results for the direct effect of neuronal derived $\mathrm{NO}$, the inhibition of 20-HETE (vasoconstriction agent) by NO, the interaction of EET (astrocyte derived vasodilation agent), and their corresponding vessel response, as an expansion of the EET generation model in Bennet's study [5].

\section{Author details}

'National Institutes for mathematical Sciences, Daejeon, 305-811, Republic of Korea. ${ }^{2}$ Department of Electrical Engineering, Korea Advanced Institute of Science and Technology, Daejeon, 305-701, Republic of Korea.

Published: 8 July 2013 


\section{References}

1. Attwell D, Buchan AM, Charpak S, Lauritzen M, MacVicar BA, Newman EA: Glial and neuronal control of brain blood flow. Nature 2010, 468:232-243.

2. Cauli B: In Revisiting the role of neurons in neurovascular coupling. Volume 2. Front. Neuroenerg; 2010.

3. Peng X, Zhang C, Alkayed NJ, Harder DR, Koehler RC: Dependency of cortical functional hyperemia to forepaw stimulation on epoxygenase and nitric oxide synthase activities in rats. I Cereb Blood Flow Metab 2004, 24:509-517.

4. Liu X, Li C, Falck JR, Roman RJ, Harder DR, Koehler RC: Interaction of nitric oxide, 20-HETE, and EETs during functional hyperemia in whisker barrel cortex. AJP: Heart and Circulatory Physiology 2008, 295:H619-H631.

5. Bennett MR, Farnell L, Gibson WG: Origins of blood volume change due to glutamatergic synaptic activity at astrocytes abutting on arteriolar smooth muscle cells. J Theor Biol 2008, 250:172-185.

doi:10.1186/1471-2202-14-S1-P180

Cite this article as: Kang et al.: Theoretical model for neurovascular coupling via interactions of NO, EET, and 20-HETE. BMC Neuroscience 2013 14(Suppl 1):P180.

\section{Submit your next manuscript to BioMed Central} and take full advantage of:

- Convenient online submission

- Thorough peer review

- No space constraints or color figure charges

- Immediate publication on acceptance

- Inclusion in PubMed, CAS, Scopus and Google Scholar

- Research which is freely available for redistribution

Submit your manuscript at www.biomedcentral.com/submit 